Article

\title{
Social Franchising Model as a Scaling Strategy for ICT Reuse: A Case Study of an International Franchise
}

\author{
Katja Zajko ${ }^{1}$ and Barbara Bradač Hojnik ${ }^{2, *}$ \\ 1 Faculty of Organizational Sciences, University of Maribor, 2000 Maribor, Slovenia; katja.zajko@gmail.com \\ 2 Faculty of Economics and Business, University of Maribor, 2000 Maribor, Slovenia \\ * Correspondence: barbara.bradac@um.si; Tel.: +386-2-22-90-256
}

Received: 5 July 2018; Accepted: 29 August 2018; Published: 3 September 2018

\begin{abstract}
Reuse is a type of concept meant to solve environmental problems and can be implemented in different models. This study explores the social franchising model in the area of ICT reuse, relying on a case study of international social franchise and a comparative analysis of its three franchisees. The concept of the proposed social franchising model is based on a theoretical framework and a case study organization analysis, and has four developmental phases with nine identified key factors, which are essential to creating the necessary systematic approach for a successful outcome by creating both economic and social impact on a scale. This article contributes to the social entrepreneurship literature by analyzing success factors that have allowed our case study to operate as a highly successful franchise. The empirical part of the paper employs a case study of the organization to provide evidence of the existing model for social franchising in the reuse of ICT in Ireland, the U.S. and Slovenia. The paper concludes by revealing the social franchising model framework in the reuse of ICT.
\end{abstract}

Keywords: scalability; social enterprises; ICT reuse; social franchising; business model; key factors; case study

\section{Introduction}

In business environments, the social entrepreneurship concept is a fast developing part of the economy. It is a relatively new topic, which is gathering researchers' attention because of social input and the boom in this kind of business [1]. Consequently, new business models have emerged, such as social enterprises that have the potential to alter the ways in which we think about our role within economic systems. These enterprises are responding to business environments with new challenges such as long-term unemployment, climate change, sustained development and social responsibility [2,3]. Therefore, social enterprises are social, mission-driven organizations that develop an entrepreneurial activity (make products and/or deliver goods and services) in order to fulfil unsolved social needs in society [4]. One of the main challenges for social entrepreneurs has been to scale up their venture. Although these entrepreneurs may have a clear understanding of the needs in a given community and are able to raise the necessary capital to start a social venture, they are frequently unable to develop or scale up the service delivery, marketing and accountability challenges that all small businesses face [5]. Consequently, the impact of social entrepreneurs is usually limited to a specific region or local environment. Therefore, there is growing interest in business models which could help extending initiatives to further locations and let more people benefit from the products and services. Dees et al. [6] claim that there are several questions social entrepreneurs should ask themselves in order to understand the most efficient way and the most favourable strategy of scaling 
their innovation. Scaling social innovations is associated with several challenges due to the complexity of social problems and the scarcity of investor incentives, in combination with an overall absence of will to strive for scale. Bull et al. [7] define successful scaling with the result of a decrease in the level of need relative to a specific problem by an increase in the number of people whose needs are being fulfilled by a successful approach. Scaling up is equally significant for social enterprises as it is for other sectors, but several social enterprises are still young and the focus is usually on short-term performance rather than long-term sustainability [8]. Social enterprises might not have the resources or the capability to grow immediately, which probably requires a plan for a long-term growth strategy, according to Austin et al. [9]. Westley et al. [10] stress that numerous social enterprises fail to scale up and, therefore, there is a search for organizational models to simplify the progression of scaling social impact [11].

Franchising can represent an effective approach and scaling strategy to mastering the complexities to replicate a proven concept. It not only promises to help address the question of how to provide innovative entrepreneurs with the structure and support necessary to convert their interest in social enterprises into sustainable businesses, but it also provides a roadmap for implementing these ventures. Social franchising is an adaptation of commercial franchising in which the developer of a successful social concept (franchisor) enables others (franchisees) to replicate the model using a proven system and a brand name to achieve a social benefit. Social franchising can be defined as a system of contractual relationships, which use the structure of a commercial franchise to achieve social goals [12]. As such, it is a new institutional arrangement in the field of social entrepreneurship and it represents a promising leveraging tool to achieve social goals and represents the most promising strategy for encouraging growth and disseminating best practices. Although there is now a substantive body of literature on business format franchising, little is known about the distinctive nature of social franchising [13].

Companies participating in the social economy operate within various industries and serve several groups of customers. One industry is the reuse of information and communication technology (ICT), which is an important part in social movement that aims for ethical, responsible and sustainable consumption. Reusing used ICT products offers the possibility to implement business ideas and establish successful companies operating in this industry. However, it is important to be aware of and consider several key factors that significantly contribute to companies' success. The practice of reuse manages to generate a wide range of ancillary social and economic benefits ranging from providing employment and training opportunities for people with disabilities or the long-term unemployed to providing access to suitable equipment for people with low incomes in both the developed and the developing world, thus helping to bridge the digital divide [14]. It is also a major source of ICT equipment for businesses and educational organizations in the developing world to help promote vitally needed economic development $[15,16]$. Nevertheless, reuse as an economic activity is not yet fully recognized, and there is a lack of consensus on how it should be implemented and regulated. The current state of knowledge and practice in the area of waste electrical and electronic equipment (WEEE) reuse is very fragmented across Europe and is extremely difficult to translate across national borders. With only a few notable exceptions, the current state of reuse across Europe is very low, and the barriers to reuse are multiple: Collection systems often do not allow for the proper handling of reusable products; consumers often store products for long periods before returning them, and thus any potential economic value is lost; access to the waste stream can be restricted by vested interests; permitting and licensing arrangements can be restrictive for small operators; training and up-skilling for employees is inaccessible; and the activities of illegal operators give the business a bad reputation [17]. This decentralized nature of the industry, in contrast to the decentralized nature of reuse, presents a technical and institutional challenge to the development of successful social enterprises, and therefore to the mainstreaming of reuse. These social enterprises often lack the technical, financial and political skills to be able to develop successful operations.

Further, despite the merits of previous research $[13,18,19]$, we still lack a comprehensive understanding on drivers of successful scalability in social enterprises. Thus, to fill a gap and develop 
the field of scaling up in social entrepreneurship, by an empirical research that investigates the social franchising model, as scaling strategy and explores the key factors in the perspective of the social franchise.

Our paper aims to address this problem through an explorative case study of a social franchise operating with ICT reuse and a comparative analysis of its three franchisees.

This study's findings contribute to the literature on scaling social enterprises $[8,10,11,18,19]$, social franchising $[12,13]$ and reuse of ICT [14,17].

First, our work provides useful insights for the research stream investigating social enterprise scale-up $[18,19]$. Additionally, characteristics of the ICT reuse industry are presented as one of the forms of social enterprises. Our findings show that the decentralized nature of the industry, in contrast to the decentralized nature of reuse, presents a technical and institutional challenge to the development of successful enterprises, and therefore to the mainstreaming of reuse. These small-, medium- and micro-sized enterprises (SMMEs), which are usually social enterprises, often lack the technical, financial and political skills to be able to develop successful operations.

The second contribution of this paper is associated with the identification of key successful factors for the development of a social franchising model in the area of ICT reuse. Specifically, our findings show that overall development of the model has four distinct stages for successful work, namely preparation, piloting, implementation and replication with adaptation.

Given their characteristics, social enterprises operating in the reuse of ICT, are usually on a small scale and are city-based activities limited to a specific catchment area (usually a single local authority) and linked to the eco-system of waste management in that region [15]. However, with the presented case study organization and its three franchisees in different geographical locations, we provide the evidence of success factors that contribute to the implementation of the social franchising model in the area of ICT reuse.

This paper is organized as follows: The following section presents a review of the literature and the research questions, the third describes the adopted methodology, the fourth presents the results of the study, and the last provides discussion, conclusions and possible further research.

\section{Literature Review}

\subsection{Social Franchising as A Strategy for Scale Social Enterprises}

The discussion on the scalability of social enterprises is relatively heterogeneous [20,21]. Weber et al. [22] define scaling as "the most effective and efficient possible increase in social impact created by a social enterprise based on its operational model, with the goal of satisfying the demand for the relevant product or service". Despite the range of definitions of scalability and scaling, the literature on social entrepreneurship seems to reflect a broad consensus that replicability, adaptability, and transferability of the operational model are key components of scalability [23,24]. This perception is also supported by commercial scalability literature [24,25]. Replicability means the capacity to reproduce or adopt the social enterprise's structures, processes, products or services, and habits [6,25]. Adaptability means the capacity to adjust the social enterprise's structures, processes, products or services, and/or its habits $[25,26]$. Transferability unifies replicability and adaptability on the basis of the following reasoning. In line with previous research [19,25-27], it is stated that pure replication (e.g., to new geographic locations without any adjustment) is comparatively rare because current knowledge and processes almost always have to be adapted to new conditions [28]. All determinants of a basic operational model usually cannot be copied to the social enterprise's new site. Therefore, the replicability of the operational model and the necessary adjustments for successful adaptation to a new geographic area must be considered first. Breaking transferability down into the two separate key components of replicability and adaptability thus allows researchers to analyse the scaling process in a more differentiated way [19]. 
Several of the studies in scaling up in social entrepreneurship are concentrated on strategies and processes. Lyon and Fernandez [18] did a case study with the aim to study different strategies social enterprises can use to scale up their impact. The cases they used are from the early year's sector of supporting children and families. Outcomes from the study displayed that several strategies, depending on the capacities of the organizations, could increase the social impact. They point out that social enterprises need to develop several strategies to maximize their social impact [18]. Authors [18] argue that further research is needed to explore scaling social impact on a diversity of social enterprise approaches.

While early work on scaling focused on how people and policies inside the organization can affect the growth of social impact [23,29], more recent attention has focused on how interaction with their external ecosystems can help the scaling of social entrepreneurial organizations, creating alliances to acquire resources and political support [30,31], building on market incentives to change the behaviours of beneficiaries and influencers, and capitalizing on economic and social trends to attract attention and build momentum for their causes [9,32]. Similarly, Pinelli and Maiolini [33] investigated different perspectives on capabilities, which affect sustainability agendas of organizations. Particularly, as claimed by Pinelli and Maiolini [33], static models identify internal opportunities while developmental models are based on stakeholders' expectations. However, to achieve scalability, organizations should be able to identify external stimuli, adopt and translate them with internal capabilities into organizational objectives.

Theoretical work has largely focused on the development of practitioner frameworks. In the same way, the empirical work that has been done, specifically to understand the drivers of successful scaling for social entrepreneurial organizations, has been limited, with most of it utilizing comparative case-study approaches $[22,30,31]$. There exists a wide range of terminologies for factors that accelerate the scaling process, expressions such as scalers [28,32], drivers [34], success factors [20] and capacities [32].

Bloom and Chatterji [28] identified drivers—or organizational capabilities—of the scaling process and developed a conceptual model labelled the SCALERS model, which consists of Staffing, Communicating, Alliance-building, Lobbying, Earnings-generation, Replicating and Stimulating market forces. The purpose of The SCALERS Model is to help social entrepreneurs understand the factors of scaling social impact and growing their enterprises. There are probably specific characteristics of the enterprise's internal and external environment that will energize or mitigate a SCALERS's impact. In some cases, efficient distribution of all the SCALERS is needed to scale up successfully, but in some cases, an efficient distribution of only a few SCALERS might impact successful scaling. The SCALERS Model is significant in two ways. The first is that it recognizes seven particular actions that social enterprises might undertake to scale social impact, by concentrating on the interface between the enterprise and the context in which it operates. The second way is that the model consists of situational contingencies, which limit the direct relationship between each SCALERS and the scaling of social impact [11]. Cannatelli [11] also points out the lack of empirical research in the field of scaling up in social entrepreneurship. As indicated in these studies, scaling up requires capabilities and actions from the social enterprises, and The SCALERS Model is a theoretical model that displays potential paths to achieve scaling. As discussed above, this model has been developed in order to get higher validity as a theoretical model, but it still needs to be developed. The model does not explain why many social enterprises fail to scale up.

Weber et al. [19] developed a scalability framework, where the aim was to classify, integrate, and relate the central theoretical and empirical findings in the topic of scaling up in social entrepreneurship. Even though there is a growing knowledge of the complexity in the literature; there is no developed model that indicates strategies, drivers, and obstacles of scaling social impact. The development of The Scalability Framework should fill this gap. The research has provided a comprehensive approach and significant new understandings of the processes and capabilities of social enterprises. The identified key components in the framework are Commitment of the Individuals 
Driving the Scaling Process, Management Competence, Entire or Partial Replicability of the Operational Model, Ability to Meet Social Demands, Ability to Obtain Necessary Resources, Potential Effectiveness of Scaling Social Impact with Others, and Adaptability. These seven key components are identified through 241 key drivers from the relevant literature of scaling social impact. Each component is critical for scaling, which makes the framework a guide for social entrepreneurs in their scaling processes [19].

Scaling can also come through external developments beyond the confines of the organisation, such as social franchising. Social franchise facilitates the scaling up of the business to fulfil social needs. The concept of social franchising has been increasingly addressed by the business sector and investigated by several prior studies [12,35-37]. Central to franchising is having a business model that is proven and suitable to a franchise relationship $[37,38]$. Business format franchising consists of a contractual relationship between two independent firms in which a parent company (the franchisor), having developed a product or service, agrees to allow another firm (the franchisee) to sell that product or service in a specific way, in a particular location, and during a given period in return for a one-off initial fee and an annual sales-based payment [39]. Although there is now a substantive body of literature on business format franchising, little is known about the distinctive nature of social franchising, which requires a tried and tested business model [12]. In this respect, social entrepreneurs can learn from commercial franchising, where effective franchise systems comprise (1) a strong brand, (2) products and services that have been shown to be competitive in relevant markets, and (3) the franchisor's ability to give ongoing and effective assistance to the franchisees [29]. Furthermore, Ziólkowska [40] identified six success factors for social franchising: A proven and replicable social business model, social value with a focus on service delivery, careful selection of franchisees, access to financial resources, social mission commitment, and exchange of knowledge. First of all, a proven and replicable social business model is a success factor. The starting point of social franchise development is a well-established business concept when the pilot phase is finished. Success is measured both by success in reaching social goals and by the ability to demonstrate profitability. That it is replicable means that it has been possible to describe and standardise the most critical processes in the enterprise so that someone else can follow them. Secondly, social value is an added value, with a focus on service delivery. A social enterprise must, in the first instance, deliver quality services or products to its customers. Furthermore, careful selection of franchisees is an extremely important issue in social franchising. Regardless of how good the franchise is, wrong entrepreneurs can cause the business to fail. A franchisor exerts the greatest influence on the future outcome of the business during the choice of franchisees. Since replication leads to increased cooperation and more contracting in the non-profit sector, it is essential to have workable franchisees. The most ideal franchisees are a type of 'entrepreneur-lite': They must have the drive and skills to lead and own their own business, but cannot be so entrepreneurial and opportunistic that they are not able to follow the franchise system they have signed up to. The development of a social franchise also requires access to financial resources. The franchisor must have financial resources in order to develop the concept. A crucial factor is to remain true to the social mission of the social enterprise. As demands from employees, financiers and other stakeholders increase, so many other aspects become important for survival. Franchisors are also required to create a platform to exchange knowledge within the system [40].

\subsection{ICT Reuse Industry Characteristics}

Over the past few decades, interest in studies on ICT reuse has been increasing [41,42]. As such, the literature has increasingly emphasized the importance of integrating the sustainability concept into organizational business models [43], with a focus on creating a sustainable organization that aims to act proactively to implement environmental and social practices. Therefore, reuse is contributing to the environmental, social and economic optimization of the product life cycle. By extending the use phase of electrical and electronic equipment (EEE) or its potentially reusable components and, thus, substituting for the use of newly produced EEE or its components, reuse can enhance resource and energy efficiency over the entire product life cycle. In particular, scholars have defined potential 
for reuse as the ecologic, economic and social advantageousness of reuse compared to direct product recycling and disposal. This definition recognizes the fact that reuse does not always constitute the optimal solution at a product's end-of-life, as the product type and condition, the energy-efficiency of comparable new substitute products and other contextual factors influence the reuse potential [43].

Throughout the last 20 years, rapid growth of ICT reused product consumption has gained researchers' attention and raised the question, why do customers purchase ICT re-used products? One possible answer is that for economic and ecological reasons customers are now more interested in reused products rather than new products [44]. A vital part of any system that aims to achieve reuse is to generate and sustain markets for the products that have been refurbished. The micro-economic literature in this space all points to the ability to reliably signal quality as being crucial in instilling confidence in customers. Consequently, the public awareness, branding and warranty have to be developed to generate the right conditions for a market for reused equipment to flourish [45]. A public awareness campaign is an essential element, as final markets for the reused products are essential for the ongoing success of the endeavours. A reuse organisation should have its own unique brand and labelling scheme that a certified and compliant refurbisher can attach, using clearly visible labels, to reused products fit for resale. Under a pre-defined standard, a minimum warranty of one year is directed and should be the minimum requirement of a reuse organisation membership.

The consumption of ICT re-used products is also considered one of the best strategies to protect the environment because it saves natural resources that would have been used for a new product and protects the environment by preventing the used products from becoming waste. Reuse is the only way to conserve the many critical raw materials that products contain for which no recycling technologies exist. For example, there is currently no recovery of high-tech elements like antimony, arsenic, beryllium, silicon, gallium, germanium and rare earth elements and close to zero recovery rates for tantalum, lithium and magnesium. Longer lifetime through reuse gives an opportunity for such recycling technologies to develop and keeps a larger stock of resources for the urban mine of the future. From a social perspective, reuse makes high quality equipment available to low income households, helping to bridge the "digital divide" and provide access to the benefits of ICT across society [46]. Still, many customers may feel uncertain about the quality of the reused products, instead preferring to purchase new products, especially when a warranty is provided [47].

Compared just to recycling, reuse conserves the embodied energy and water, which are consumed in vast quantities in electronics manufacturing. Additionally, the interests of the growing recycling industry can cause potential tensions between "reuse of products" and "recycling of materials". In this regard, the recent concept of a "circular economy" prioritizes reuse, repair and remanufacturing of products and components over mere material recycling, as these activities preserve inherent product value and yield more environmental benefits in comparison with recycling [48]. These savings easily outweigh the additional energy consumed by delaying their replacement with more energy-efficient products. At the same time, informal cannibalising of electronic waste and illegal dumping of electronics residues is a significant environmental problem. The recent EU-funded project CWIT (Countering WEEE Illegal Trade) estimated that of 9.45 million tonnes of WEEE generated in Europe, 2.2 million tonnes is collected and processed under non-compliant conditions, and 3.2 million tonnes remains undocumented [46].

Article 11 of the Waste Framework Directive 2008/98/EC [49], among others, calls for the "establishment and support of re-use and repair networks". Reuse organizations are generally social enterprises that work closely with the community, employ groups that are usually excluded from employment, and are non-profit and in receipt of social employment supports. These small, medium and micro sized enterprises (SMMEs) often lack the technical, financial and political skills to be able to develop successful operations.

Furthermore, as explored by Kissling et al. [43], a list of generic success factors and barriers, which are relevant to the reuse operating model, were identified. On the one hand, the difficulty in accessing sufficient volumes of good quality used equipment and the lack of legislations, which support, 
incentivize and-if necessary-enforces this access, were identified as the most impactful barriers. On the other hand, the quality and reliability of products distributed for reuse, control and securing of product and process quality, access to high quality used equipment and stakeholder relationship management (trust of supplying and receiving customers, reputation, positive recognition and presence in media, political backing, network of influential contacts) were ranked as the most important success factors. Reuse organizations adhering to good reuse practices, differentiate themselves through quality guarantee from non-compliant, informal competitors through quality guarantees. Moreover, proven quality strengthens important stakeholders' confidence in reuse and in stakeholders like suppliers, customers, authorities and the general public.

However, the barriers to reuse are manifold [43]:

- Collection systems often do not allow for the proper handling of reusable products;

- Consumers often store products for long periods before returning them, and thus any potential economic value is lost;

- Access to the waste stream can be restricted by vested interests;

- Permitting and licensing arrangements can be restrictive for small operators;

- Training and up-skilling for employees is inaccessible; and

- The activities of illegal operators give the business a bad reputation.

Given their characteristics, reuse organizations can form a partnership, which operates as a social franchise, encourages the involvement of new organisations, and develops into a synergistic network that can operate at a scale capable of overcoming the current problems they face. Once joining the network, operators are given the right to employ previously tested incentives, including professional training, use of brands or brand advertisements, subsidized or proprietary supplies and equipment, support services, and access to professional advice.

Replication is by no means a simple project of transfer, especially when complex systems like reuse organizations are involved in the process [13]. Our work intends to deal with these problems by addressing the following research question: What are the key success factors that explain the development of the social franchising model in the area of ICT reuse?

\subsection{Analytical Framework of Identified Success Factors in the Literature for Developing Social Franchise in the Area of ICT Reuse}

According to the purpose of this paper, and to answer the research question, we developed an analytical framework of the success factors for developing a social franchise in the area of ICT reuse (Table 1). We identified key success factors based on The SCALERS Model [28], The Scalability Framework [19] and social franchising literature [40]. Additionally, we identified in our framework success factors for ICT reuse operating models [17]. 
Table 1. Identified success factors in the literature for developing social franchise in the area of ICT reuse.

\begin{tabular}{|c|c|c|c|c|}
\hline Model & $\begin{array}{l}\text { SCALERS Model Success } \\
\text { Drivers/Factors }\end{array}$ & Scalability Framework Key Components & Social Franchising Success Factors & $\begin{array}{c}\text { Success Factors of ICT Reuse Operating } \\
\text { Models }\end{array}$ \\
\hline Success factors & $\begin{array}{ll}\text { 1. } & \text { Staffing, } \\
\text { 2. } & \text { Communicating, } \\
\text { 3. } & \text { Alliance-building, } \\
\text { 4. Lobbying, } \\
\text { 5. Earnings-generation, } \\
\text { 6. } \\
\text { 7. } & \text { Stimulating market forces. }\end{array}$ & $\begin{array}{l}\text { 1. Commitment of the individuals } \\
\text { driving the scaling process, } \\
\text { 2. Management competence, } \\
\text { 3. Entire or partial replicability of the } \\
\text { operational model, } \\
\text { 4. Ability to meet social demands, } \\
\text { 5. Ability to obtain necessary resources, } \\
\text { 6. Potential effectiveness of scaling } \\
\text { 7ocial impact with others, and } \\
\text { 7. Adaptability. }\end{array}$ & $\begin{array}{l}\text { 1. Proven and replicable social } \\
\text { business model, } \\
\text { 2. Social value with a focus on } \\
\text { service delivery, } \\
\text { 3. Careful selection of franchisees, } \\
\text { 4. Access to financial resources, } \\
\text { 5. Social mission commitment and } \\
\text { 6. Exchange of knowledge. }\end{array}$ & 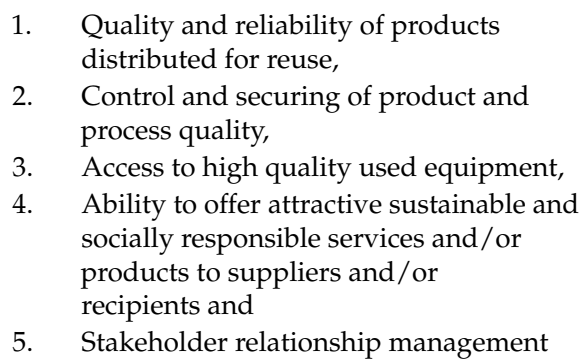 \\
\hline
\end{tabular}

Source: Authors' elaboration. 


\section{Methodology}

Given the lack of empirical and theoretical understanding of the key successful factors for the development of a social franchising model [12], a case study approach was adopted to collect data. A case study is considered an appropriate strategy for answering research questions that ask "how" and "why", and that do not require control over events [50]; as such, questions deal with operational links that need to be traced over time, rather than mere frequencies or incidence. By using a case study approach, the reason why particular decisions were made, how they were implemented and how results were obtained can be identified and understood. A quantitative evaluation can hardly be imagined if we consider the small number of existing social franchises. Consequently, we focus on current events and concerns and seek to answer questions of how and why. Yin [51] favours exploratory case studies only when available research or the existing knowledge base is poor, as in the field of social franchising.

This present study was designed as a case study of a social franchise operating in the reuse of ICT, comprising three social franchisees (Irish franchisee, U.S. franchisee, and Slovenian franchisee). The selected case study has successfully scaled up by using social franchising strategy. The data were collected from two different sources: documents and interviews. Documents included franchise agreements, business plans, online materials, newspaper clippings and magazine articles. In addition, we conducted semi-structured interviews with the franchisor and its three franchisees. A total of four personal interviews were conducted with a director or CEO.

The interviews were prepared with two well-elaborated interview guides with open-ended questions, which left space to follow-up questions and made the interviews flexible. It was one interview guide for the franchisor (Appendix A) and one interview guide for its three franchisees (Appendix B). These kinds of interviews make it easier for the participants to answer from their view and opinions, but there is still control over the questioning, and that was significant for this study. To explore our main research goal "To identify key success factors that explain the development of the social franchising model in the area of ICT reuse", interview questions are structured focusing on five research sub-objectives, which are:

- To investigate business experience and resources needed for the establishment of the case study organization.

- To investigate which are key success factors of the operational model of the case study organization.

- To investigate what the key characteristics for successful member of the case study organization are.

- To investigate if in the case study organisation exists training services, ongoing support and marketing support when replicating their business.

- To investigate the adaptation process of the operational model of the case study organization to the local environment based on the comparison of three franchisees in three different geographical areas.

Links between interview questions and research goals are presented in Table 2. 
Table 2. Overview of the key interview questions linked with the research objectives.

\begin{tabular}{|c|c|}
\hline Research Sub-Objectives & Key Interview Questions \\
\hline $\begin{array}{l}\text { Research sub-objective 1.1: } \\
\text { To investigate business experience } \\
\text { and resources needed for the } \\
\text { establishment of the franchise. }\end{array}$ & $\begin{array}{l}\text { - Can you tell me your business experience? How many years of } \\
\text { experience do you have in this industry? In this business? } \\
\text { - Where did you get resources to set up this business? } \\
\text { (e.g., governmental support, own capital.) }\end{array}$ \\
\hline $\begin{array}{l}\text { Research sub-objective 1.2: } \\
\text { To investigate, what the key } \\
\text { success factors of the operational } \\
\text { model of the franchise are. }\end{array}$ & $\begin{array}{l}\text { - What is your business model? How do you make your money? } \\
\text { - Could you outline and describe your operational model from the } \\
\text { supply, process and market perspective? Where do you get your } \\
\text { products? How do you process them and where do you sell them? } \\
\text { Which are, in your opinion, the key factors for the successful } \\
\text { implementation of the model? }\end{array}$ \\
\hline $\begin{array}{l}\text { Research sub objective 1.3: } \\
\text { To investigate the key } \\
\text { characteristics for a successful } \\
\text { member. }\end{array}$ & $\begin{array}{l}\text { - On what basis do you choose your franchisees? } \\
\text { - Based on your experiences, what are the most important attributes } \\
\text { of a successful franchisee? }\end{array}$ \\
\hline $\begin{array}{l}\text { Research sub-objective 1.4: } \\
\text { To investigate, whether in the case } \\
\text { study organisation there exists } \\
\text { training services, ongoing support } \\
\text { and marketing support when } \\
\text { replicating their business }\end{array}$ & $\begin{array}{l}\text { - What initial services do you offer to your franchisees? } \\
\text { - Is there any custom-designed software that you use? } \\
\text { - Do you provide on-going training in the form of courses, } \\
\text { - Workshops, conferences, seminars, regional meetings? } \\
\text { or service offered by the franchisees? }\end{array}$ \\
\hline $\begin{array}{l}\text { Research sub-objective 1.5: } \\
\text { To investigate the adaptation } \\
\text { process of the operational model to } \\
\text { the local environment based on the } \\
\text { comparison of three franchisees in } \\
\text { three different geographical areas }\end{array}$ & $\begin{array}{l}\text { - Was adaptation process difficult? } \\
\text { - Is there any local authority support provided? (e.g., governmental } \\
\text { support for social enterprises or local authority support). } \\
\text { - Has each franchisee adopted your brand? } \\
\text { - What were the challenges? Geographical spread, different } \\
\text { culture, etc.? }\end{array}$ \\
\hline
\end{tabular}

Source: Authors' elaboration.

We adopted the following techniques suggested by Eisenhardt [52] to analyse the data: (1) analysing within case data, (2) searching for cross-case patterns, (3) enfolding literature, and (4) reaching closure. The case analysis is based on a classic content analysis, but it does not require data to be quantified. To begin with, a system of categories was developed based on theoretical treatment of the data (theoretically deductive). In the second phase, this category system was complemented with results from the field under investigation (empirically inductive).

\section{Results}

This section is presented in three parts. First, we describe the case study organization since its establishment and its operating business model starting from its establishment and how the organization is creating economic, social and environmental value. Additionally, we compare all three franchisee members of the case study, from a geographical perspective and highlight the specifics mentioned by the director or CEO when adopting the operating model.

Thereafter, based on the theoretical framework, the insights from the case study organization and a comparative analysis of the three franchisees as they adopt the operating model, we identify key success factors (internal and external) for the development of the social franchising model, operating in the area of ICT reuse. 


\subsection{Description of Case Study Organization}

The case study organization is a not-for-profit organisation based in Ireland. It was founded in April 2014 by a group of like-minded individuals who wanted to help develop the commercial activity of social enterprises that operate mainly in the area of reuse of ICT equipment and WEEE. The organization describes its mission as follows:

"To provide employment opportunities of individuals of all kind of abilities and from all backgrounds through the sale of high quality refurbished ICT equipment." (case study organization, interview with the director).

"Within five years, social franchise hopes to become Europe's largest electronic and electrical equipment asset recovery organisation and provider of IT and electrical equipment for social enterprises." (case study organization, online press release).

The analysis of the case study organization's current operating business model can identify a range of enterprising elements within the organization that have been developed to meet the social, environmental and economic impact. These include goals such as collecting, processing and distributing ICT equipment as laid out in Figure 1.

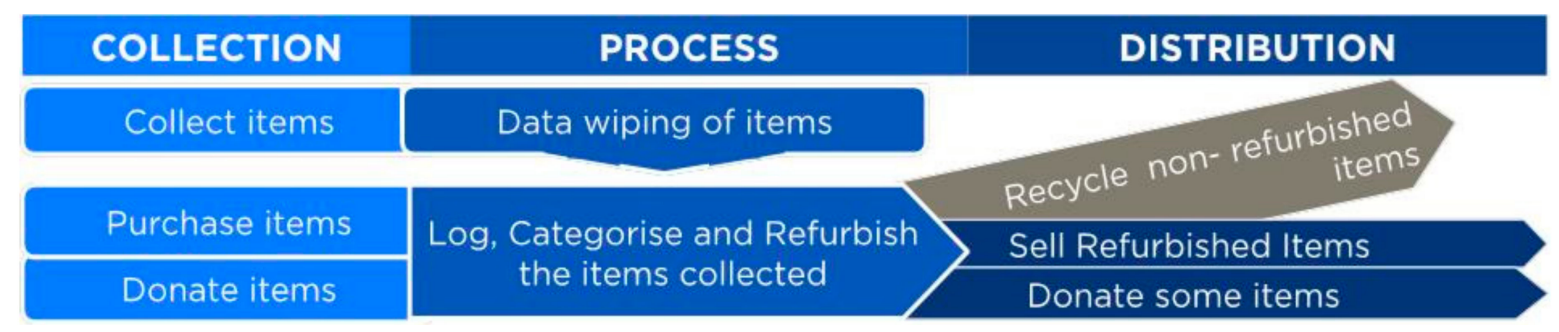

Figure 1. The case study organization's business model. (Source: case study organization business plan.)

\subsubsection{Collection of ICT Equipment}

To secure a supply of business-to-business (B2B) and business-to-consumer (B2C) material, the case study organization established relationships with large commercial companies, local authorities, compliance schemes, retailers, schools, charities and government departments. WEEE that has potential for reuse is segregated at the point of collection at retailers, civic amenity sites, special collection days and kerbside/household collections and is subsequently processed in the case study organization's state-of-the-art facilities in three different regions.

"For us it is crucial to get the right material in the door. It is very important that we get high quality equipment, which we are able to offer to our demanding customers." (case study organization, interview with the director).

\subsubsection{Processing ICT Equipment}

Reuse as an activity must be regulated, as it needs to take place in a sustainable fashion and to eradicate "sham-reuse". This can only be done by setting standards that refurbishers must achieve before they can gain access to reusable equipment. The case study organization has achieved the most appropriate current standard for reuse: PAS 141. A production process involves the refurbishment of equipment and disassembly for recovery of useable parts and components. Equipment that is deemed not to have potential for reuse upon inspection and testing is returned to the current compliance scheme, is processed, and is reported under the existing conditions.

"Reuse as an activity must be regulated as it needs to take a place in a sustainable fashion. It is essential that "sham-reuse" is eradicated. This can only be done by setting standards, which refurbishers must 
achieve before they can gain access with equipment with potential for reuse. We have implemented standard PAS 141, which enables us to reach the highest quality and get confidence into our products." (case study organization, interview with the director).

The case study organization has developed an asset recovery software system solution to process WEEE and reuse ICT. This system is a data capture system for inventory and the measurement of impact through reuse and covers all aspect of the WEEE and preparation for reuse legislation (case study organization, online material).

"We are currently undertaking the following activities in preparation for the reuse process: visual inspection, safety test, function test, data eradication, software removal/uploading, disassembly, repair and testing and cleaning." (case study organization, interview with the director).

\subsubsection{Distribution, Demand and Market for Refurbished ICT Equipment}

The customer base and markets for refurbished ICT equipment are quite significant in size. The case study organization has divided the main target markets into the following groups (case study organization, business plan):

- Academic \& Educational—schools \& colleges, training centres;

- Charities \& non-profit organizations;

- Local authorities and others with Green Public Procurement mandates;

- Students-individual end-user students across all levels (first, second, third \& part time students);

- Eligible Recipients—as per Microsoft licensing specifications, eligible recipients include people who are disadvantaged in some way (disability, unemployed, living in a disadvantaged area etc.);

- Trade-local trade \& international brokerage markets;

- Business Users-SMMEs, start-up companies; and

- E-commerce-developing innovative and engaging websites and apps selling directly to end users.

"Our market is very demanding and includes potential franchisees and all customers who want to buy high quality low cost refurbished equipment and save money." (case study organization, interview with the director).

The case study organization's revenue model is based on proceeds from refurbished ICT equipment sales and fees from its franchisees. The organization was looking to scale up social impact and therefore increase employment opportunities for disadvantaged individuals through ICT equipment refurbishment opportunities. Based on the success of their work in Ireland and on the company's strategic objectives, the organization identified that a social franchising approach would be the best model to scale their network and replicate their social impact. The case study organization has expanded to three countries to date, namely Ireland, the U.S. and Slovenia. Based on their experiences, the case study organization identified the key characteristics for a successful member, which are provided in Table 3 (case study organization, archival data).

"This step was very important for the development and growth of our company, as this is how we identify which member has the managerial experiences and resources to adopt the company's operating model. We certainly don't want to waste our time and others time, if the partner is not appropriate." (case study organization, interview with the director). 
Table 3. Key characteristics for a successful member identified by the case study organization.

\begin{tabular}{|c|c|c|}
\hline Section & Essential Elements & Desirable Elements \\
\hline $\begin{array}{l}\text { Leadership \& } \\
\text { Experience }\end{array}$ & $\begin{array}{l}\text { - Buy-in from all stakeholders, } \\
\text { General Manager with supply } \\
\text { chain experience. }\end{array}$ & $\begin{array}{l}\text { - Experience in waste reuse, } \\
\text { Experience working with } \\
\text { large corporates. }\end{array}$ \\
\hline $\begin{array}{l}\text { Organizational } \\
\text { Services }\end{array}$ & $\begin{array}{l}\text { - } \quad \text { Existing organisational operational } \\
\text { teams, such as HR, finance etc. }\end{array}$ & \\
\hline Values \& Interests & $\begin{array}{l}\text { - Access to a pipeline of people of } \\
\text { all abilities, } \\
\text { - Right attitude and committed } \\
\text { to values. }\end{array}$ & \\
\hline Financial Situation & $\begin{array}{l}\text { - Money to invest and cover } \\
\text { operating costs, } \\
\text { - } \quad \text { Experience managing large budgets. }\end{array}$ & $\begin{array}{l}\text { - Experience of tendering } \\
\text { for contracts. }\end{array}$ \\
\hline Premises & - $\quad$ Ability to access a site. & - $\quad$ Existing site \& facilities. \\
\hline Partnerships & - $\quad$ Ability to build local partnerships. & $\begin{array}{l}\text { - } \quad \text { Access to customer market, } \\
\text { - } \quad \text { Existing links with key partners, } \\
\text { - } \quad \text { Links with waste } \\
\text { management facilities. }\end{array}$ \\
\hline Technology & - Internet \& phone line on-site. & \\
\hline Legal & $\begin{array}{l}\text { - Organisation has non-profit status } \\
\text { (e.g., 501C, social enterprise) }\end{array}$ & \\
\hline
\end{tabular}

Source: Authors' elaboration from interview with director and from archival data of case study organization.

Since its launch in 2014, the case study organization and its three franchisees have managed to refurbish, sell and donate almost 150,000 pieces of refurbished ICT equipment. They distribute high-quality ICT equipment among thousands of non-profit organisations and schools across Europe and the U.S. and provide jobs for 170 people with a job through the distribution of these units.

In its capacity as the franchisor, the case study organization is responsible for the handover of the concept and the training of the franchisees, and as well in some cases, for the supply of refurbished ICT equipment. In addition, the organization constantly supports its franchisees through supplementary training, consultation services, knowledge transfer, and sharing effective practices, and it takes on part of the marketing activities as well. The company's international team brings a wealth of experience from the commercial WEEE and ICT reuse sectors. They have developed a range of tools and resources to enable social enterprises to have a meaningful impact and generate operation-sustaining profit to sustain their operations. The franchising fee to be paid to the case study organization comprises an initial fee and annual sales-based payments and mainly serves to cover the refurbishment process and network development (case study organization, business plan).

Figure 2 shows an overview of the case study organization's basic structure-the franchisor and its three franchisees, which we describe in the Section 2.1. Despite the fact that the case study uses a relatively young organization, established in 2014, it consists of well experienced individuals who have experience and knowledge in the ICT reuse industry and have gained the attraction from many social enterprises who want to adopt the model. 


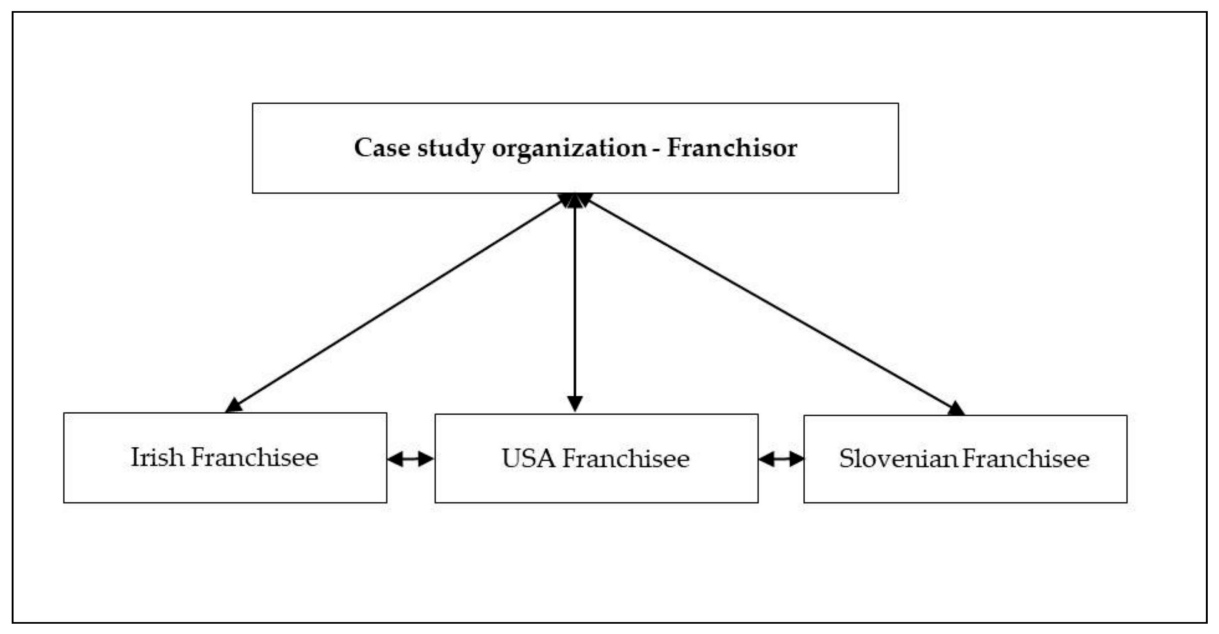

Figure 2. Franchise structure of the case study organization. (Source: Authors' elaboration.)

\subsection{Overview of Case Study Organization'S Franchisees}

\subsubsection{Irish Franchisee}

The Irish franchisee is a limited company by guarantee that provides training opportunities for disadvantaged people and it is specialised in the area of reuse of ICT and WEEE. The company was established in 2013 and currently employs 35 people to date, over one-third of them are people with disabilities.

Irish franchisee states its mission as follows:

"To provide high quality refurbished ICT equipment and create real jobs for people with disabilities and therefore flourish and maximize the economic, social and environmental impact." (Irish franchisee, interview with the director).

Primary delivered services are the collection of ICT equipment and WEEE with the potential for reuse, refurbishment of ICT equipment and resale of reused equipment. The quality of the reused products in franchisee is crucial to create demand and to instil confidence in customers.

The refurbishment of ICT products at the Ireland franchisee location is fully operational and implemented to the known industry best standards, with PAS 141 certification, which provides a framework for those involved in reuse to help minimise the impact of WEEE on the environment and to assure consumers that refurbished products are fit for purpose both in terms of safety and function.

"Our primary delivered services are collection of ICT equipment and WEEE with potential for reuse, refurbishment of ICT equipment under PAS 141 standard and resale of these equipment to our markets. We believe quality of the reused products is crucial to create demand." (Irish franchisee, interview with the director).

Acquisition of ICT products is gained mainly from the B2B market, which means contracts with manufacturers and other IT commercial organisations, government departments, local authorities and other large corporations. WEEE is collected from retailers in cooperation with the compliance schemes.

The revenue model is based on the reselling of the quality, low-cost, refurbished ICT equipment to schools, charities, businesses and end users in the Irish and UK market. As such, the organization is capable of funding itself entirely through the revenues it generates itself and is thus largely independent of donations and third-party funds. On the other hand, the Irish franchisee strongly engages with the local community, which has an important role in providing encouragement that is important for the development of reuse centres. 
"To date, more than 90,000 ICT equipment has been reused, resold and donated. Support of local employment services help us a lot to follow our mission. With Tús programme, we have integrated more than 80 people with disabilities, who have found meaningful jobs through training services that we provide. Based on a tested and efficient business model along with a well-known brand that was adopted from the franchisor, our franchisee has succeeded in providing an economic, environmental and social impact and fully adopt the operational model." (Irish franchisee, interview with the director).

In terms of local authority support, the Irish franchisee is closely working with local employment services, which are running a Tús programme. The Tús initiative is a community work-placement scheme providing short-term working opportunities for unemployed people. Additionally, in Ireland, supportive funds for social enterprises have been established by Social Innovation Ireland (SIFI) in partnership with Local Authorities of Ireland and funded by the Department of Rural and Community Development. The programme is designed to help social enterprises develop their business skills and to provide them with ongoing peer support and advice so that they can develop sustainable enterprises that have a powerful impact in their community.

\subsubsection{U.S. Franchisee}

The U.S. franchisee has been established in 2015 and is a part of a non-profit organization 501(c)(3) that serves individuals with disabilities inclusive of wounded warriors seeking employment training and career opportunities. Despite over 50 years of existence, the organization felt the need to develop new services in the field of the reuse of ICT and thus, become more independent of government subsidies. The U.S. franchisee describes its mission as following:

"We serve any individual who has experienced a life-changing incident requiring them to learn a new occupational skill, any individual experiencing behavioural health issues and any wounded warrior. We also offer housing opportunities for individuals who require supported living and who are diagnosed with a serious mental illness." (U.S. franchisee, interview with the CEO).

Over many years, the U.S. franchisee has found that the development of in-house enterprises has created many employment and training opportunities. As mentioned, in 2015, the U.S. franchisee was launched as a new enterprise, operating in the area of ICT reuse, which is a franchisee of case study organization. The U.S. franchisee adopted an operating model and offers dynamic business solution in areas spanning (1) Information Security Management (ISM), (2) IT Asset Recovery Services (ARS) and (3) Recycling. The organization employs 130 people, half of which are people with disabilities (U.S. franchisee, archival data).

The business model is based on having an enterprise that is not reliant only on grants and donations, but as a business that insures sustainability while offering services in the area of ICT reuse. Approximately half of the income comes from ICT reuse services, while another half comes from federal and state government contracts, which are used to subsidise training programs for people with disabilities.

The franchisee's objectives include creating the conditions for the reuse of ICT to flourish and to maximize the economic, social and environmental benefits that will stimulate a sustainable level of refurbishment and marketing, such as (U.S. franchisee, business plan):

(1) Create employment in ICT refurbishment \& retail of ICT;

(2) Provide training opportunities

(3) Offer low-cost equipment available to marginalized groups \& individuals;

(4) Reduce waste and promote the reuse of ICT; and

(5) Make financial contributions and ensure sustainability.

In its capacity as the franchisor, the case study organization is responsible for the handover of the concept and the training of the franchisee. In addition, the franchisor constantly supports its 
franchisees through supplementary training and consultation services, and it takes on part of the marketing activities (U.S. franchisee, franchise agreement).

"When looking to adapt a business model to suit a U.S. culture, it was important to consider the impact on our cultural and local market demands. It was important to consider also that, geographical distance and different time zones. Sometimes it was difficult to communicate, like to get instant online assistance." (U.S. franchisee, interview with the CEO).

The key to success for the U.S. franchisee is its capability to adapt to the franchisor's ICT reuse operating model with compliance, process and certification. This expertise along with the marketing and remarketing for both the source and sale of material is developed in partnership with the franchisor. The franchisee adopted the business model from the franchisor based on three pillars: source, processing and remarketing. However, the franchisee did not adopt the brand, as they have their own well-known, established brand.

"I am running this organization for the last 25 years and I had a desire to expand business in the recycling of the ICT equipment. I believe that the capability of adaptation of the process by required standards and promotion are key elements to the success of our franchisee. Our brand is a well-known in the state of Arizona and we weren't sure, if we go ahead with new brand, as it might confuse our customers. So we decided not to adopt the franchisor brand." (U.S. franchisee, interview with the $\mathrm{CEO}$ ).

The U.S. franchisee is specialized in offering asset recovery services and collecting used equipment from corporate users. This equipment is either purchased or is sometimes donated. Data sanitation and certification for compliant reuse, recycling and disposal respectively build a crucial part of an asset recovery service, since corporate users are particularly concerned about secure destruction of all information and data stored on the used equipment. The equipment in U.S. corporate companies have a faster return and are more up-to-date, which is, on the other hand, important to fulfil market demand. The refurbishment process is managed under the PAS 141 standard.

"Adaptation of asset recovery software system was challenging, as customary units had to be localized (for example, the currency EUR had to be changed into the US dollar, kilograms to pounds, kilometres to miles etc.), which incurred additional costs." (U.S. franchisee, interview with the CEO).

Similarly, as in the case study organization, products are sold to local partners, which are mostly educational institutions, local NGOs and not-for-profit organizations. Some equipment is sold to trade customers and through an e-commerce website to end users. By adopting an e-commerce platform and a social media presence to fit the local U.S. market culture, the case study organization puts increased focus on localizing to fit the local market culture. The U.S. franchisee is looking to expand its market into neighbouring Mexico.

"We sell our products to local charities, schools and end users. We are working closely with franchisor, he is providing us with some marketing material, which we use and adopt into our local market. We are present at our local NGO days, open days for schools, shows to promote our business. At the moment we working hard to promote our website and looking the opportunities in our neighbour country Mexico." (U.S. franchisee, interview with the CEO).

Indeed, the local community plays an important role in providing encouragement, which is important for the U.S. franchisee. The local population is a direct user of the franchisee, and they donate used equipment on open days, purchase used equipment or take part in the reuse organization activities as volunteers.

The supportive institutional context in the U.S. largely consists of private organizations that provide financial support, education, training, research, and consulting services for social enterprise. 
In the U.S., most outside financial and other support for strategic development of social enterprise comes from private foundations as opposed to the government [51]. Some limited, mostly indirect, government support for social enterprise is found at the local, state, and federal levels in the U.S. For example, in our case, the U.S. franchisee has a support from community development programs sponsored by the government, which are not directly aimed at the development of social enterprise per se, but who are providing substantial support in the case of U.S. franchisees, such as government contracts for people with disabilities.

"We are currently looking to apply for the fund for social enterprises in the frame of Bill \& Melinda Gates Foundation. At the moment we are receiving governmental and federal support for people with disabilities." (U.S. franchisee, interview with the CEO).

\subsubsection{Slovenian Franchisee}

The Slovenian franchisee is a limited company, registered as social enterprise, established in 2016 with the purpose of creating job opportunities for disadvantaged people in the area of ICT reuse. To date, the company employs five staff members, one-third of whom are disadvantaged people.

Slovenian franchisee describes it mission as following:

"To provide low cost high quality refurbished ICT equipment and create real jobs for people with disabilities" (Slovenian franchisee, online resource).

The keys to success were the managerial experiences of the social enterprise and the capability to transform from the Irish operating business model into a Slovenian model, and its connection with local authority and local employment services. The Slovenian franchisee has a strategic geographic location and is serving neighbouring markets in Austria, Italy, Hungary and Croatia. The business model ensures its sustainability through the sale of refurbished ICT equipment and is not reliant on grants. There is also a focus on quality provisioning with staff training, especially for young unemployed people, therefore ensuring maximum social impact. Attention is also given to the environmental impact with regard to reuse of ICT.

"I think that the key to successful establishment of franchisee was capability to transfer and adopt Irish model, which is more commercially driven. I am glad that we found that kind of social franchise, as in Slovenia is missing key entrepreneurial competences and business drive in social enterprises. I also believe that my previous leadership competences, gained from experiences in both-pure commercial industry and in not for profit organization-contribute to the successful growth of the company. If you want to run a social enterprise, you have to have commercial experiences and you have to be able to attract the right people to get necessary resources. So at the start, we got support from a local mayor, who provided us with necessary space for the operation of the business." (Slovenian franchisee, interview with the director).

Supply of the refurbished equipment is currently distributed directly from the franchisor and in some minor cases from corporate companies in Slovenia. Direct B2B supply from corporate companies in Slovenia is at the moment a challenge, because many companies already have contracts for asset recovery services, and they are not interested in changing their partner. Also, Slovenian companies do not turnover ICT equipment as fast as corporations in Ireland or in the U.S. Therefore, currently the supply relies mainly on the franchisor and on brokers.

"In the first phase is crucial for us to establish the market. So we are putting all efforts on the demand side of the business. Supply, which is of course also very important aspect of our business, is currently gained mainly from the franchisor in Ireland, brokers and some local companies in Slovenia. In the second phase we are planning to develop asset recovery business here locally." (Slovenian franchisee, interview with the director). 
High attention is given to the process of the equipment and implementation of standard PAS 141, ensuring maximum product quality and safety. Quality certification gives a remarkable competitive advantage in providing customer confidence in the refurbished ICT product. As described above, the equipment is sold to the educational sector, charities, businesses, trade customers and end users through an e-commerce platform. The Slovenian franchisee adopted a recognizable brand and it is expanding its markets into neighbourhood countries.

Adaptation and replication of the proven operational model of the case study organization in Ireland to the Slovenian franchisee was relying on the support of the local authority, which recognized a potential in the development of sustainable social enterprise when adopting a successful operational model in the reuse of ICT. The local authority provided a space to start the Slovenian franchisee's operations. In the adaptation phase, as in the example of the U.S. franchisee, it was important to consider some cultural and market differences, as Slovenians are not as willing to buy refurbished equipment as the Irish or Americans. With a recognizable brand and promotion, the Slovenian franchisee is developing a positive reputation and customer confidence.

"Of course there was a bit challenge, when adopting Irish model in Slovenia. First, the mind-set and cultural differences between both countries are affecting day-to-day activities, especially regarding marketing. I have witnessed that customers here in Slovenia are precise and more demanding when it comes to the refurbishment equipment, as customers in Ireland or in U.S. Therefore, we need a lot more efforts and promotion to establish a confidence in the customers. I think that is because second-hand products in general have bad reputation in Slovenia." (Slovenian franchisee, interview with the director).

However, the institutional framework also plays a role in the development of the Slovenian franchisee. The new Law of Social Entrepreneurship in 2011 was the basis for the Strategy of Social Entrepreneurship in Slovenia, as prepared by the Ministry of Economic Development and Technology. The Ministry also established the Council for Social Entrepreneurship, whose main aim is to design the politics of development of social entrepreneurship by involving other ministries, government offices, municipalities, social partners and organizations of civil society. The Slovenian franchisee was granted 20,000 EUR for start-up social enterprises.

"The support is in a way provided by the government, but it still shows the lack of understanding of the role of social entrepreneurship. Mechanisms and support are not always well distributed and properly defined. For example, in Ireland and in the U.S., the educational sector is the biggest customer of refurbished ICT. That is not the case in the field of reuse of ICT in Slovenia, in spite of the provided institutional framework in Slovenia and the associated support mechanisms. Instead of supporting green procurement for social enterprises and encouraging schools to buy refurbished ICT, the government puts forward barriers such as financing schools with money only to be used to buy new equipment." (Slovenian franchisee, interview with the director).

The results of the comparative analysis of all three franchisees are presented in Table 4 . 
Table 4. Comparison of case study organization's three franchisees by their key characteristics.

\begin{tabular}{|c|c|c|c|}
\hline \multirow{2}{*}{$\begin{array}{l}\text { Element of } \\
\text { Comparison }\end{array}$} & \multicolumn{3}{|c|}{ Case study Organization-Social Franchise in the ICT Reuse } \\
\hline & Irish Franchisee & U.S. Franchisee & Slovenian Franchisee \\
\hline $\begin{array}{l}\text { Managerial } \\
\text { competences }\end{array}$ & $\begin{array}{l}\text { CEO has managerial experiences and competences } \\
\text { in the ICT reuse industry. }\end{array}$ & $\begin{array}{l}\text { CEO has managerial experiences and competences in } \\
\text { charity }\end{array}$ & $\begin{array}{l}\text { Director has managerial experiences and competences in } \\
\text { commercial company }\end{array}$ \\
\hline $\begin{array}{l}\text { Resources for the } \\
\text { establishment }\end{array}$ & $\begin{array}{l}\text { Franchisee got support for establishment from } \\
\text { individuals, who run franchisee and from local } \\
\text { authority. }\end{array}$ & $\begin{array}{l}\text { Franchisee got support from its sister enterprise and } \\
\text { from government. }\end{array}$ & $\begin{array}{l}\text { Franchisee got government support for start-up social } \\
\text { enterprise, support from Irish franchisor and support from } \\
\text { local authority. }\end{array}$ \\
\hline Market/Recipient & $\begin{array}{l}\text { - } \quad \text { Educational sector-schools \& colleges, } \\
\text { training centres, } \\
\text { - Non-profit organizations, } \\
\text { - Students, } \\
\text { - Trade, } \\
\text { - } \quad \text { Business Users-SMMEs, start-up companies, } \\
\text { - End users (B2C). }\end{array}$ & $\begin{array}{l}\text { - Educational sector-schools \& colleges, } \\
\text { training centres, } \\
\text { - Non-profit organizations, } \\
\text { - } \quad \text { Students, } \\
\text { - } \quad \text { End users (B2C). }\end{array}$ & $\begin{array}{l}\text { - Educational sector-schools \& colleges, training centres, } \\
\text { - } \\
\text { - Students, } \\
\text { - } \text { Trade, } \\
\text { - } \text { Eusiness Users-SMMEs, start-up companies, } \\
\text { End (B2C). }\end{array}$ \\
\hline Geographical focus & Ireland, UK & Arizona, Mexico & Slovenia, Italy, Croatia, Austria \\
\hline Supply (source) & $\begin{array}{l}\text { - Mainly from B2B (directly from corporates), } \\
\text { - B2C-from compliance schemes, } \\
\text { - Brokers. }\end{array}$ & $\begin{array}{l}\text { - From B2B (directly from corporates), } \\
\text { - B2C-mainly donations, } \\
\text { Brokers. }\end{array}$ & $\begin{array}{l}\text { - Currently mainly from the network (franchisor), } \\
\text { - } \quad \text { Brokers, } \\
\text { Small part directly from B2B. }\end{array}$ \\
\hline $\begin{array}{l}\text { Creation of economic, } \\
\text { social and } \\
\text { environmental impact }\end{array}$ & $\begin{array}{l}\text { - Contract with employment services for } \\
\text { training people with disabilities. } \\
\text { - Reuse of ICT and diverting e-waste } \\
\text { from landfill. } \\
\text { Sustainable business with providing asset } \\
\text { recovery services and reselling } \\
\text { refurbished equipment. }\end{array}$ & $\begin{array}{l}\text { - State government contracts for training people } \\
\text { with disabilities. } \\
\text { - } \quad \text { Reuse of ICT and diverting e-waste from landfill. } \\
\text { Services and reselling refurbished equipment. }\end{array}$ & $\begin{array}{l}\text { - Contract with employment services for training } \\
\text { young unemployed } \\
\text { - Reuse of ICT and diverting e-waste from landfill } \\
\text { - Sustainable business with reselling } \\
\text { refurbished equipment. }\end{array}$ \\
\hline Process and system & $\begin{array}{l}\text { - Asset recovery services, refurbishment under } \\
\text { the standard PAS 141, } \\
\text { - Using asset-recovery software system. }\end{array}$ & $\begin{array}{l}\text { - Asset recovery services, refurbishment under the } \\
\text { standard PAS } 141 \text {, } \\
\text { - Using asset-recovery software system. }\end{array}$ & $\begin{array}{l}\text { - Refurbishment process under standard PAS } 141, \\
\text { - Using asset-recovery software system. }\end{array}$ \\
\hline Local Authority support & $\begin{array}{l}\text { Local authority support was one of key factors for } \\
\text { the establishment of franchisee. }\end{array}$ & $\begin{array}{l}\text { Local authority support was one of key factors for the } \\
\text { establishment of franchisee. }\end{array}$ & $\begin{array}{l}\text { Local authority support was one of key factors for the } \\
\text { establishment of franchisee. }\end{array}$ \\
\hline Brand/Promotion & Brand was adopted. & Brand was not adopted. & Brand was adopted. \\
\hline $\begin{array}{l}\text { Supportive institutional } \\
\text { framework }\end{array}$ & $\begin{array}{l}\text { TÚS programme for providing short-term working } \\
\text { opportunities for unemployed people. }\end{array}$ & $\begin{array}{l}\text { Community development programmes sponsored by } \\
\text { government and federal contracts. }\end{array}$ & $\begin{array}{l}\text { Ministry of Economic Development and Technology, local } \\
\text { government initiatives, which support development of social } \\
\text { enterprises. }\end{array}$ \\
\hline Legal form & Limited Company by Guarantee. & Charity 501(c) & Limited company, registered as social enterprise \\
\hline Adaptation of the model & Entire adoption of the model without distinction. & Adoption of the model with certain adjustments. & Adoption of the model with certain adjustments. \\
\hline
\end{tabular}




\subsection{Development of Social Franchising Model}

The case study of a social franchise and a cross comparison of its three franchisees in different geographical areas demonstrates a method for multiplying social value creation as opposed to the multiplication of economic value creation pursued by commercial franchises. Cooperation is based on a legal agreement between the franchisor and franchisee, as is customary with the traditional franchising model. In this agreement, the case study organization appears as the franchisor, while the local multipliers are autonomous units-social enterprises that act as franchisees. The case study organization as a franchisor offers a strong initial and on-going offer to franchisee that share its mission and who is looking to develop more sustainable income streams in the area of ICT reuse, which includes:

- Training services in order to help professionalize the franchisee which is working or wish to work in the reuse industry;

- Professional services to the franchisee to achieve a sufficient supply of equipment for its sustainability;

- Technical support to reuse organisation in setting up and operation and operations manuals;

- Use of asset recovery software system and PAS 141 standard;

- Use of brand and promotion;

- Sales and marketing support to the franchisee; and

- Ongoing support and quality assurance to continue to develop the asset recovery processes for the reuse of ICT equipment and increase in reuse and reduction of WEEE.

In return, the franchisees pay franchisee fees, provide data and comply with quality controls. As in commercial scalability literature, the comprehensive social franchising model was developed while requiring an investment on an ongoing basis to sustain the network. It best met requirements primarily related to quality assurance and revenue generation. As shown in Figure 3, the overall development of the model has four distinct phases, which include (1) preparation, (2) piloting, (3) implementation, and (4) replication and adaptation. Based on the literature review and on the analysis of the case study organization with the franchisees, we identified nine key factors, from which seven are external and two internal key factors, that contribute to the successful development and operation of the social franchising model in the area of ICT reuse. In the developed framework, with four different stages of the case study organization, the identified external key factors are: market/recipients, B2B and B2C supply, training/employment, asset recovery software system and PAS 141 standard, local authority, brand/promotion and supportive institutional framework. Furthermore, there are also two internal key factors identified, which consist of managerial competences and resources. To achieve scalability, the organization should consider external signals and then adopt and develop an internal organization based on the capabilities, as proposed by Pinelli and Maiolini [33]. 


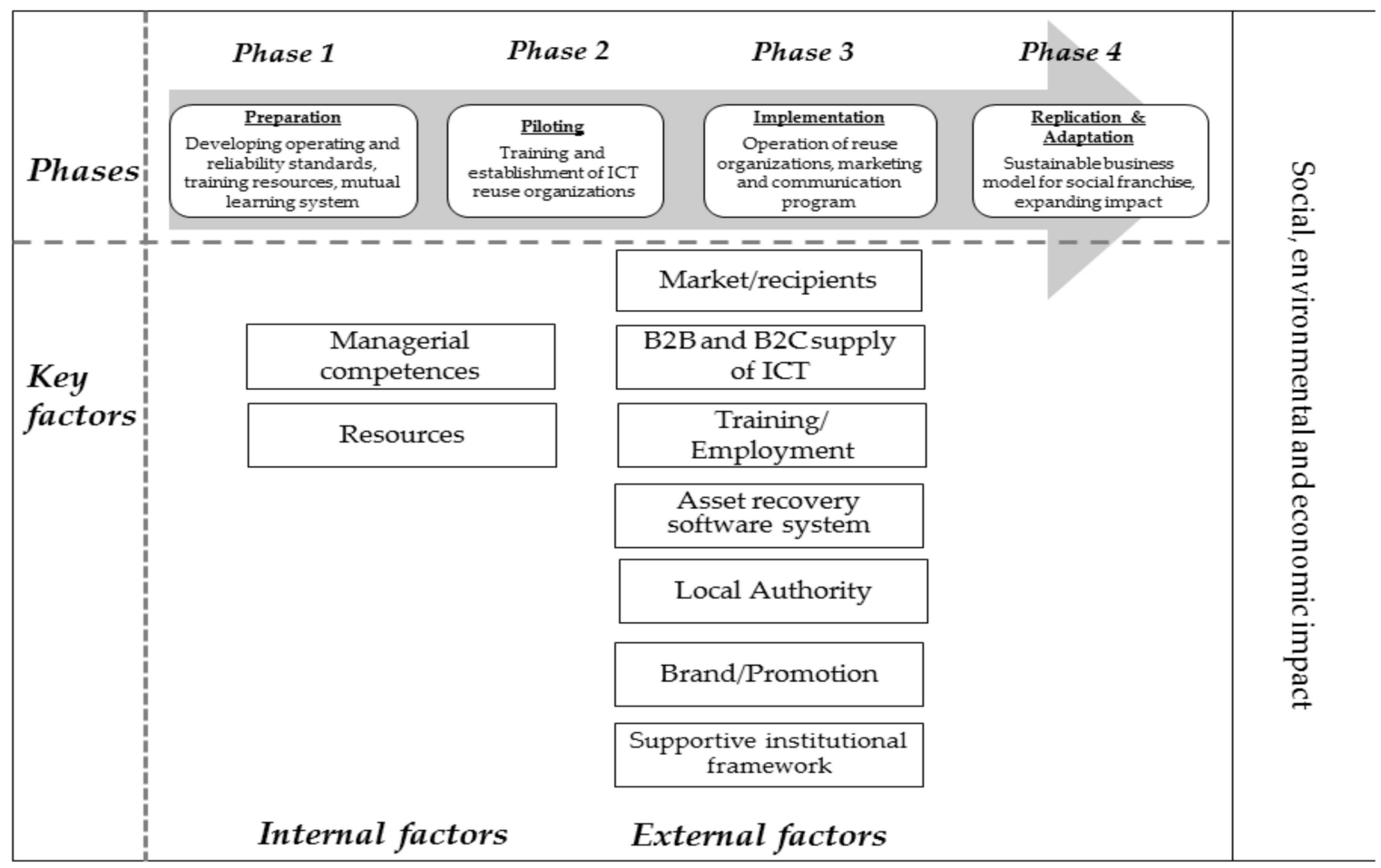

Figure 3. Social franchising model operating in the ICT reuse. (Source: authors' development.)

In the following, each phase of the developed model is described in detail.

Phase 1: Preparation. Prior to piloting the franchising model, the case study organization developed a set of operating and reliability standards, training resources and a mutual learning system that supports the process of plotting the operational and business model for the franchisee and considering regional specifics. The case study organization improved their readiness to replicate by recruiting the right local team to operate the franchise network and build evidence of the potential success of the business model in Europe and the U.S., building on their success in Ireland.

Phase 2: Piloting. This stage is focused on the training and establishment of a reuse organization working in the area of ICT reuse. That includes full technical specifications and protocols, business and service plans, policies and procedures and structural and legal requirements. These can be adapted to the local conditions and legislation of each region. The supply (amount, types, configuration and age of ICT equipment) is assessed by various approaches, including market data from WEEE regulators and modelling product residence to identify device flows.

Phase 3: Implementation. Once the franchising model has been successfully completed the pilot phase, complete operations are carried out, as all plans are implemented in full. Life cycle assessments are employed to quantify the environmental benefits of the reuse operations and to measure the impact. Production involves both refurbishment of equipment and disassembly for the recovery of useable parts and components. The franchisees sell refurbished equipment directly or through retail outlets. In this phase, products are branded with the newly developed quality label, and franchisees are networked to share experiences and even transfer products between them as the market dictates.

Phase 4: Replication $\mathcal{E}$ adaptation. The final phase of the case study organization's franchise model is ensuring long-term sustainability through the establishment and implementation of a business plan, which enables the replication and promulgation of the proposed model across Europe and the U.S. As a part of this activity, it is vitally important to develop and manage a network of close observers made up of suitable local authorities. With regard to standardization, a distinction can be made between two competing aspects: The necessity of a sufficiently flexible system package for adaptation to local conditions, and the significance of product and process standardization of products and processes. 
Just like commercial franchises, social franchises adapt to local conditions. The case study organization allows all their franchisees the necessary leeway for the implementation of the concept on site.

Challenges of the case study organization's franchising model are:

- Competing with firms that feign a social mission or confuse the social service marketplace solely for the purpose of enhancing owner and / or shareholder value;

- Navigating complex resource allocation decision environments where multiple stakeholders must be satisfied;

- Maintaining continuous innovation in both business practice and social mission environments;

- Attracting and retaining management talent while competing in a for-profit compensation environment;

- Developing meaningful measurement and reporting processes that accurately model social value creation for the short-, medium- and long-term;

- Finding the right partner who has met all the criteria that the case study organization developed; and

- Adapting the model to its cultural and environmental specifics.

We have argued that the case study demonstrates the enduring success of the social franchise model and is based on internal and external factors. They are based on the capabilities of the organization on the capacity of how to create value; accumulate assets through effective business practice in the area of ICT reuse using a scale economy; while also remaining close to the stakeholders and community, and creating social value.

\section{Discussion and Conclusions}

Our in-depth, inductive study aimed to disentangle the key factors that explain a successful social franchising model operating in the reuse of ICT. By answering this research question, we contribute to literature investigating scalability strategies for social enterprises $[6-8,10-13,19,28]$ and the reuse industry [14-17] in several ways.

The first contribution is associated with an analysis of the case study organization, which enables us to identify typical patterns for the development of the social franchising model operating in the area of ICT reuse. The case study showed that the overall development of the social franchising model is based on the theory of commercial scalability $[25,29]$ and has four distinct stages, namely preparation, piloting, implementation and replication, along with adaptation.

First, the preparation phase is important because this give the insights into the development of operating and reliability standards and training resources that support plotting the operational and business model process for the franchisee, considering regional specifics. The second phase, piloting, is fundamental for the training and the establishment of the ICT reuse organization. That includes full technical specification and protocols, business and service plans, policies and procedures and structural and legal requirements, which can be adapted to the local conditions in each region. The third phase of project implementation is important to operationalize all activities and thus concretely move the franchisee toward a sustainable model in terms of creating an economic, social and environmental impact. The final phase, replication and adaptation, ensures long-term sustainability through establishing and implementing a business plan that enables the replication and promulgation of the proposed model across Europe and the U.S. The replication of the case study organization social franchising model operating in three different regions significantly contributes to the environmental impact and reuse of waste in particular. By refurbishing and reselling ICT equipment, the company realizes the true value of that equipment, generates real sustainable employment opportunities for disabled/disadvantaged people, and reduces environmental hazards by reducing the amount of waste going to landfills. Our findings are consistent with prior studies [13] which revealed that success is measured by both success in reaching social goals and an ability to demonstrate profitability. 
Second, the comparison of all three franchisees allows us to identify nine key factors that contribute to the successful operation of a social franchising model operating in the ICT reuse in three different geographical areas. We identified seven external key factors (market/recipients, B2B and B2C supply, training/employment, asset recovery, software system \& PAS 141 standard, local authority, brand/promotion and supportive institutional framework) and two internal key factors (managerial competences and resources). These findings are consistent with literature on the ICT reuse industry, which has acknowledged the role of key success factors in the reuse organizations $[17,43,45,47]$. Additionally, our findings are consistent with the literature on scaling social impact where managerial competences and resources are success drivers to enable the scale of social enterprise [19]. Our findings further extend these studies by providing empirical evidence of the importance of each key factor in the frame of the social franchising model of the case study organization.

Previous research has emphasized that the challenge facing social enterprises is how to scale up their impact beyond small successful projects [6]. Our study reveals valuable insights to organisations that are willing to scale their business as a social franchise in the area of ICT reuse. The primary factor distinguishing this successful social franchising model is how it has evolved to create value and accumulate assets through effective business practices using scale economies while remaining close to and relevant in the communities that it serves. The case study organization overcomes these challenges, which include, on the one hand, financial sustainability and creating social value on the other hand. Furthermore, the replication of the case study organization business model as a social franchise through innovation, training, software system, process development and commercialization with a recognizable brand also contributes to the development and acceleration of the social enterprise model.

Finally, our study reveals that adaptation to different cultural and geographical environments requires the model to be adjusted. This is sometimes challenging due to local institutional frameworks and geographical location, which is in line with previous studies [28]. Not all determinants of a basic operational model can usually be copied to the social enterprise's new site. The example of the U.S. and Slovenian franchisees shows that there was a successful adaptation of the operating model, but with a few adjustments to the local environment and institutional frame, which was not the case in the Irish franchisee. The U.S. franchisee case showed that there were necessary localization changes needed for the software system for asset recovery to meet local legal requirements. In addition, the brand from the franchisor was not adopted in the U.S. market, as the franchisee had already established its own well-known brand. However, all other aspects of the operating model were successfully transferred into the U.S. market, despite the mentioned adjustment and a few challenges regarding geographical location. Furthermore, as the case of the Slovenian franchisee shows, in this context, in the adaptation phase, like in the example of the U.S. franchisee, it was important to consider some cultural and market differences, as Slovenians are not as willing to buy refurbished equipment as Irish or Americans. However, with the adopted recognizable brand and promotion, the Slovenian franchisee is developing a positive reputation and customer confidence.

Last but not least, our study reveals that the demonstrated social franchising model is able to leverage the advantages of scale as it creates valuable capital while also retaining specific unique knowledge about the needs of the local community. Thus, researches and practitioners should look at the social franchising model as one way to solve social and environmental problems at scale.

Our study opens several new avenues for further research. First, although this study provides evidence of the existence of a successful social franchise operating in the area of ICT reuse and spread in three different geographical locations, further research with more in -depth comparison analysis between Europe and the U.S. could investigate institutional framework differences between those two regions regarding social enterprises and reuse organizations.

Second, our study has pointed out the importance of only two internal key factors in the developed franchising model. However, more in-depth research is needed to identify and explore other internal key factors that might influence the success of the social franchising model to capture the attention of other social enterprises who want to scale their business. 
Finally, further research could investigate how cultural variations affect the successful implementation of the social franchising model. Indeed, all three franchisees of the case study organization are located in different geographical and cultural locations, and they are social enterprises and reuse organizations, which are in distinctive environments. Further research will deepen our knowledge of such context-specific influences.

Author Contributions: Conceptualization, K.Z. and B.B.H.; Writing-Original Draft Preparation, K.Z.; Writing-Review \& Editing, B.B.H. and K.Z.

Funding: This research received no external funding.

Conflicts of Interest: The authors declare no conflict of interest.

\section{Appendix A}

\section{Questionnaire for franchise}

\section{Research Goal No. 1: What is business experience and mission of the franchise?}

It is therefore vital that the franchisor has experience of running the sort of business that he or she is now offering as a franchise. They may already have successful franchised operations up and running; if not, they should ideally have had a pilot operation running for at least twelve months. This applies equally to locally-developed systems and franchises brought in from overseas.

- What is your business experience? How many years of experience do you have in this industry? In this business?

- Where did you get resources to set up this business? (e.g., governmental support, bank loan, own capital, ... )

- Can you describe your mission?

Research Goal No. 2: Financials and key success factors for the operational model

- How do you make your money?

- Could you outline and describe your operational model and its key factors for success?

- Is there any custom-designed software that you use?

\section{Research Goal No. 3: Key characteristics for a successful member}

- On what basis do you choose your franchisees?

- What are the most important attributes of a successful franchisee?

\section{Research Goal No. 4: Training services, ongoing support and marketing}

- What initial services do you offer to your franchisees?

- Do you provide on-going training in the form of courses, workshops, conferences, seminars, regional meetings?

- What kinds of marketing programme do you run for the product or service offered by the franchisees?

\section{Research Goal No. 5: Adaptation of the operational model to local environment}

- How well is franchisee likely to fit with your organization in terms of personal standards, aspirations and values?

- Was adaptation process difficult?

- Has each franchisee adopted your brand?

- What phases were necessary to scale up your operational model?

- What were the challenges? Geographical spread, different culture, ... ? 


\section{Appendix B}

\section{Questionnaire for franchisees}

\section{Research Goal No. 1: What is business experience and mission of the franchisee?}

- What is your business experience? How many years of experience do you have in this industry? In this business?

- Where did you get resources to set up this business? (e.g., governmental support, bank loan, own capital... )

- Can you describe your mission?

\section{Research Goal No. 2: Financials and key success factors for the operational model}

- How do you make your money?

- Could you outline and describe your operational model and its key factors for success?

\section{Research Goal No. 3: Adaptation of the operational model to local environment}

- How well is your organization likely to fit with franchise in terms of personal standards, aspirations and values?

- Was adaptation process difficult?

- Did you adopt franchisor band?

- What phases were necessary to scale up your operational model?

- What were the challenges? Geographical spread, different culture, ... ?

Marketing is fundamental to the value of a franchise-it is the pulling power of the name above the door or written on the side of the vehicle that should more than justify the ongoing royalties the franchisee pays.

What kinds of marketing programme do you run for the product or service offered by the franchisees? May I see examples? How are marketing programmes decided on? What kind of consultation is there with franchisees about what they want/need? What is the process for evaluating success?

- What dollar value is spent on marketing? How is marketing funded? How accountable is the franchisor for the funds? Am I required to spend additionally on promotions in my local area? How much? Is supplier support available?

- Do you have a launch package for a new franchised territory? What experience is this based on? What does it include? Who pays?

- What help will I receive in arranging local advertising and promotions? Are there standard promotions (e.g., radio adverts) available for my use?

- How does the franchise use social media? Are there standard pages or can I manage my own? What assistance/policies are in place to control the use of social media by franchisees?

- Please show me examples of marketing material you provide, e.g., point of sale material and promotional literature such as brochures, leaflets, sales presenters, digital advertisements, Adwords promotions.

- Is there a website promoting the franchise? Is it optimized for mobile phones? Is it GPS-enabled? Can customers buy direct from the website? If so, are franchisees recompensed for sales in their area? Online sales can be a source of friction if not properly managed-read more.

- Does the franchise carry out database-related promotions to customers? How is the database created and managed? Can franchisees choose which offers are made to which customers?

- Is there a website promoting the franchise? Is it optimized for mobile phones? Is it GPS-enabled? Can customers buy direct from the website? If so, are franchisees recompensed for sales in their area? Online sales can be a source of friction if not properly managed-read more. 


\section{References}

1. Rey-Martí, A.; Ribeiro-Soriano, D.; Palacios-Marqués, D. A bibliometric analysis of social entrepreneurship. J. Bus. Res. 2016, 69, 1651-1655. [CrossRef]

2. Phillips, R. Stakeholder Theory and Organisational Ethics; Berrett-Koehler Publishers, Inc.: San Francisco, CA, USA, 2003; ISBN 978-1576752685.

3. Holliday, C.; Schmidheiny, S.; Watts, P. Walking the Talk: The Business Case for Sustainable Development; Berrett-Koehler Publishers: San Francisco, CA, USA, 2002; ISBN 978-1576752340.

4. Crucke, S.; Decramer, A. The Development of a Measurement Instrument for the Organizational Performance of Social Enterprises. Sustainability 2016, 8, 161. [CrossRef]

5. Zahra, S.A.; Rawhouser, H.N.; Bhawe, N.; Neubaum, D.O.; Hayton, J.C. Globalization of Social Entrepreneurship Opportunities. Strat. Entrep. J. 2008, 2, 117-131. [CrossRef]

6. Dees, J.G.; Anderson, B.B.; Wei-Skillern, J. Scaling Social Impact: Strategies for spreading social innovations. Stanf. Soc. Innov. Rev. 2004, 1, 14-32.

7. Bull, D.; Hedley, S.; Nicholls, J. Growing Pains: Getting Past the Complexities of Scaling Social Impact. 2014. Available online: http:/ / www.thinknpc.org/publications/growing-pains / (accessed on 18 August 2018).

8. ATKearney. Scaling Up: Catalyzing the Social Enterprise. 2015. Available online: https: / / www.atkearney.com/documents/10192/5487100/Scaling+Up\%E2\%80\%B9Catalyzing+the+ Social+Enterprise.pdf/1f1a024a-a7a5-4763-8739-50887139df47 (accessed on 18 August 2018).

9. Austin, J.; Stevenson, H.; Wei-Skillern, J. Social and Commercial Entrepreneurship: Same, Different, or Both? Entrep. Theory Pract. 2006, 30, 1-22. [CrossRef]

10. Westley, F.; Antadze, N.; Riddell, D.J.; Robinson, K.; Geobey, S. Five Configurations for Scaling Up Social Innovation: Case Examples of Nonprofit Organizations from Canada. J. Appl. Behav. Sci. 2014, 50, 234-260. [CrossRef]

11. Cannatelli, B. Exploring the Contingencies of Scaling Social Impact: A Replication and Extension of the SCALERS Model. Int. J. Volunt. Nonprofit Organ. 2016, 28, 1-27. [CrossRef]

12. Tracy, P.; Jarvis, O. Toward a Theory of Social Venture Franchising. Entrep. Theory Pract. 2007, 31, 667-685. [CrossRef]

13. Bartilsson, S. Social Franchising-Obtaining Higher Returns from Investments for Jobs in Social Enterprises; Coompanion Göteborgsregionen: Göteborg, Sweden, 2012; Available online: http:/ / www.ekonomiaspoleczna.pl/files/ekonomiaspoleczna.pl/public/_MRR_Better_Future/Report_ Social_Franchising_120524.pdf (accessed on 30 July 2018).

14. O'Connell, M.; Fitzpatrick, C.; Hickey, S. Investigating reuse of B2C WEEE in Ireland. In Proceedings of the International Symposium on Sustainable Systems and Technology (ISSST), Arlington, VA, USA, 17-19 May 2010; pp. 1-6.

15. Streicher-Porte, M.; Marthaler, C.; Böni, H.; Schluep, M.; Camacho, A.; Hilty, L.M. One laptop per child, local refurbishment or overseas donations? Sustainability assessment of computer supply scenarios for schools in Colombia. J. Environ. Manag. 2009, 90, 3498-3511. [CrossRef] [PubMed]

16. Kahhat, R.; Williams, E. Product or waste? Importation and end-of-life processing of computers in Peru. Environ. Sci. Technol. 2009, 43, 6010-6016. [CrossRef] [PubMed]

17. Kissling, R. Best Practices in Re-Use. Success Factors and Barriers for Re-Use Operating Models; Project Report; Solving the E-Waste Problem; Empa: St. Gallen, Switzerland, 2011.

18. Lyon, F.; Fernandez, H. Third Sector Research Centre Working Paper 79; Third Sector Research Centre: Birmingham, UK, 2012.

19. Weber, C.; Kröger, A.; Lambrich, K. Scaling social enterprises-A theoretically grounded framework. In Frontiers of Entrepreneurship Research 2012, Proceedings of the Thirty-Second Annual Entrepreneurship Research Conference, TCU Campus in Fort Worth, TX, USA, 6-9 June 2012; Arthur M. Blank Center for Entrepreneurship: Babson Park, MA, USA, 2012; pp. 752-766.

20. Dacin, P.A.; Dacin, T.M.; Matear, M. Social Entrepreneurship: Why we don't need a new theory and how we move forward from here. Acad. Manag. Perspect. 2010, 24, 37-57.

21. Ramus, T.; Vaccaro, A. Stakeholders matter: How social enterprises address mission drift. J. Bus. Ethics 2014, 143, 1-16. [CrossRef] 
22. Weber, C.; Kröger, A.; Demirtas, C. Scaling Social Impact in Europe-Quantitative Analysis of National and Transnational Scaling Strategies of 358 Social Enterprises, 2015. Available online: http:/ / aei.pitt.edu.ludwig. lub.lu.se/74119/1/Scaling_social_impact.pdf (accessed on 30 July 2018).

23. Bradach, J.L. Going to Scale: The Challenge of Replicating Social Programs. Stanf. Soc. Innov. Rev. 2003, 1, $18-23$.

24. Winter, S.; Szulanski, G. Replication as Strategy. Organ. Sci. 2001, 12, 730-743. [CrossRef]

25. Von Krogh, G.; Cusumano, M.A. Three Strategies for Managing Fast Growth. MIT Sloan Manag. Rev. 2001, 42, 53-61.

26. Chakravarthy, B.S. Adaptation: A promising metaphor for strategic management. Acad. Manag. Rev. 1982, 7 , 39-61. [CrossRef]

27. Josiah, J.S. Approaches to Expand NGO Natural Resource Conservation Program Outreach. Soc. Nat. Resour. 2001, 14, 609-618. [CrossRef]

28. Bloom, P.N.; Chatterji, A.K. Scaling social entrepreneurial impact. Calif. Manag. Rev. 2009, 51, 114-133. [CrossRef]

29. Sherman, A.J. Franchising \& Licensing: Two Powerful Ways to Grow Your Business in Any Economy, 3rd ed.; AMACOM: New York, NY, USA, 2004; ISBN 978-0814472224.

30. Sharir, M.; Lerner, M. Gauging the success of social ventures initiated by individual social entrepreneurs. J. World Bus. 2005, 41, 6-20. [CrossRef]

31. Grant, H.M.; Crutchfield, L.R. Creating High-Impact Nonprofits. Available online: http:/ /www.ssireview. org/articles/entry/735/ (accessed on 8 August 2018).

32. Bloom, P.N.; Smith, B.R. Identifying the Drivers of Social Entrepreneurial Impact: Theoretical Development and an Exploratory Empirical Test of SCALERS. J. Soc. Entrep. 2010, 1, 126-145. [CrossRef]

33. Pinelli, M.; Maiolini, R. Strategies for Sustainable Development: Organizational Motivations, Stakeholders' Expectations and Sustainability Agendas. Sustain. Dev. 2017, 25, 288-298. [CrossRef]

34. The Bridgespan Group. Growth of Youth-Serving Organizations, 2005. Available online: https:/ / www.bridgespan.org/insights/library / children-youth-and-families / growth-of-youth-servingorganizations / appendices (accessed on 30 July 2018).

35. Kickul, J.; Lyons, T.S. Understanding Social Entrepreneurship: The Relentless Pursuit of Mission in an Ever Changing World; Routledge: New York, NY, USA, 2012; ISBN 978-0415884891.

36. Wei-Skillern, J.C.; Austin, J.E.; Leonard, H.; Stevenson, H. Entrepreneurship in the Social Sector; Sage: Thousand Oaks, CA, USA, 2007; ISBN 978-1412951371.

37. Combs, M.; Castrogiovanni, G. Franchising: A Review and Avenues to Greater Theoretical Diversity. J. Manag. 2004, 30, 907-931. [CrossRef]

38. Johnson, T.; Richardson, K.; Turnbull, G. Expanding Values; A Guide to Social Franchising in the Social Enterprise Sector; SESF Development Partnership, VATES Foundation: Helsinki, Finland, 2007; ISBN 978-952-5716-02-3.

39. Curran, J.; Stanworth, J. Franchising in the modern economy: Towards a theoretical understanding. Int. Small Bus. J. 1983, 2, 8-16. [CrossRef]

40. Ziólkowska, M. Success Factors and Benefits of Social Franchising as a Form of Entrepreneurship. Stud. I Mater. 2017, 23, 37-47. [CrossRef]

41. Williams, E.; Kuehr, R. Today's markets for used PCs and ways to enhance them. In Computers and the Environment: Understanding and Managing Their Impacts; Kuehr, R., Williams, E., Eds.; Springer: Cham, The Netherlands, 2003; ISBN 978-1-4020-1679-0.

42. Ilgin, M.; Gupta, S. Environmentally conscious manufacturing and product recovery (ECMPRO): A review of state of the art. J. Environ. Manag. 2010, 91, 563-591. [CrossRef] [PubMed]

43. Kissling, R.; Fitzpatrick, C.; Boenia, H.; Luepschenc, C.; Andrewd, S.; Dickensone, J. Definition of generic re-use operating models for electrical and electronic equipment. Resour. Conserv. Recycl. 2012, 65, 85-99. [CrossRef]

44. Guiot, D.; Roux, D. Second-hand Shoppers' Motivation Scale: Antecedents, Consequences, and Implications for Retailers. J. Retail. 2010, 86, 383-399. [CrossRef]

45. O'Connell, M.; Fitzpatrick, C. RE-Evaluate Reuse of Electrical and Electronic Equipment (Evaluation and Mainstreaming), EPA STRIVE Programme 2007-2013; Environmental Protection Agency: Wexford, Ireland, 2013; ISBN 978-1-84095-504-0. 
46. Huisman, J.; Botezatu, I.; Herreras, L.; Liddane, M.; Hintsa, J.; Luda di Cortemiglia, V.; Leroy, P.; Vermeersch, E.; Mohanty, S.; van den Brink, S.; et al. Countering WEEE Illegal Trade (CWIT) Summary Report, Market Assessment, Legal Analysis, Crime Analysis and Recommendations Roadmap; Countering WEEE Illegal Trade (CWIT) Consortium: Lyon, France, 2015.

47. Yeh, R.H.; Lo, H.C.; Yu, R.Y. A study of maintenance policies for second-hand products. Comput. Ind. Eng. 2010, 60, 438-444. [CrossRef]

48. Gorissen, L.; Vrancken, K.; Manshoven, S. Transition Thinking and Business Model Innovation-Towards a Transformative Business Model and New Role for the Reuse Centres of Limburg, Belgium. Sustainability 2016, 8, 112. [CrossRef]

49. European Union. Directive 2008/98/EC of the European Parliament and of the Council of 19 November 2008 on Waste and Repealing Certain Directives. Off. J. Eur. Union 2008, 312, 3-30.

50. Robson, C. Real World Research: A Resource for Social Scientists and Practitioner-Researchers; Blackwell: London, UK, 1993.

51. Yin, R.K. Case Study Research, Design and Methods, 3rd ed.; Sage: Thousand Oaks, CA, USA, 2003.

52. Eisenhardt, K.M. Building Theories from Case Study Research. Acad. Manag. Rev. 1989, 14, 532-550. [CrossRef]

(C) 2018 by the authors. Licensee MDPI, Basel, Switzerland. This article is an open access article distributed under the terms and conditions of the Creative Commons Attribution (CC BY) license (http:// creativecommons.org/licenses/by/4.0/). 